\title{
Research on the Reform of "Introduction to Kindergarten Curriculum” for Preschool Education Majors in Application-Oriented Private Universities
}

\author{
$\operatorname{Rina} \mathrm{Su}^{1,2}$ \\ ${ }^{1}$ Doctor of Education Major in Curriculum and Instruction, Center for International Education Philippine Christian \\ University, Manila, Philippines \\ ${ }^{2}$ Department of Education, Inner Mongolia Honder College of Arts and Sciences, Hohhot, China \\ Email: 1980153644@qq.com
}

How to cite this paper: $\mathrm{Su}, \mathrm{R}$. N. (2022). Research on the Reform of "Introduction to Kindergarten Curriculum" for Preschool Education Majors in Application-Oriented Private Universities. Creative Education, 13, 691-697.

https://doi.org/10.4236/ce.2022.132043

Received: January 30, 2022

Accepted: February 22, 2022

Published: February 25, 2022

Copyright $\odot 2022$ by author(s) and Scientific Research Publishing Inc. This work is licensed under the Creative Commons Attribution International License (CC BY 4.0).

http://creativecommons.org/licenses/by/4.0/

\begin{abstract}
"Introduction to Kindergarten Curriculum" is a core course of preschool education major in application-oriented private universities. At present, most of the courses are academic rational orientation. There are the following challenges in teaching: The teaching content is theoretical and biased towards the "discipline-centered orientation"; The teaching method is single, and the traditional teaching of teachers is the main one; Teaching evaluation pays attention to scores and focuses on result evaluation. This is not accord with the training objectives of application-oriented private universities. Faced with such challenges, we need to carry out curriculum reform and innovation, take problems as the main line and optimize curriculum content; take students as the main body and change teaching methods; focus on process evaluation, enrich the evaluation methods. Through curriculum reform and innovation, we can adapt to the development direction of application-oriented private universities, improve the teaching effect of "Introduction to Kindergarten Curriculum", and cultivate high-quality talents of preschool education specialty.
\end{abstract}

\section{Keywords}

Application-Oriented Private Universities, Introduction to Kindergarten Curriculum, Student Center, Reform and Innovation

\section{Introduction}

By the end of 2018, China's private universities accounted for $28.13 \%$ of the na- 
tional colleges and universities ( $\mathrm{Li}, 2020)$. Application-oriented private universities are an important part of China's higher education. In order to meet the needs of connotative development and high-quality development of higher education in the new era, it is necessary to cultivate high-quality preschool education talents in applied-oriented universities (Lei et al., 2020; Xu, 2019). My school is an application-oriented private university. The characteristics of talents in application-oriented private universities lie in "applying what they have learned", emphasizing applicability, practicality and sociality (Liu \& Pei, 2019). The major I teach is preschool education, and its training talents are mainly kindergarten teachers. Kindergarten teachers are typical representatives of applied talents. Kindergarten teachers should have solid theoretical knowledge, and more importantly, the ability to apply theoretical knowledge. "Introduction to Kindergarten Curriculum" is the core curriculum of preschool education specialty. It is an intermediary curriculum from theory to practice, and it is a curriculum that points systematic kindergarten curriculum theory to concrete kindergarten practice (Liu \& Li, 2021). Theoretical is mainly reflected in the relevant knowledge of curriculum theory in each chapter and the classic theoretical scheme of kindergarten curriculum. It is intended to master the basic theoretical knowledge of kindergarten curriculum objectives, contents, implementation, evaluation and other elements on the basis of curriculum view, so that students can form theoretical literacy of preschool education teaching, thus laying a good foundation for preschool education teaching. Practicality means that on the basis of mastering curriculum theory, students can design appropriate kindergarten curriculum objectives, form the ability to write preschool education activity lesson plans, initially have the ability to implement and evaluate kindergarten curriculum, and write complete unit theme activity plans. It can be seen that "Introduction to Kindergarten Curriculum" is not a purely theoretical subject, and it should be reflected both theoretically and practically in teaching. However, by consulting the literature and combining with the subject "Introduction to Kindergarten Curriculum" I taught, it was found that the course attaches importance to theory teaching and despises practice, which cannot meet the needs of modern college students, and cannot achieve the training objectives of application-oriented private universities, and it is difficult to achieve the teaching objectives of the course. This means that the curriculum is in urgent need of curriculum innovation to change the current curriculum dilemma.

\section{The Challenges in the Teaching of "Introduction to Kindergarten Curriculum" in Application-Oriented Private Universities}

\subsection{The Teaching Content Is Theoretical, Biased towards the "Discipline-Centered Orientation"}

For a long time, the "Introduction to kindergarten curriculum" always stays in academic rationalism, emphasizing the systematicness and logic of the discipline 
( $\mathrm{Liu} \& \mathrm{Li}, 2021$ ). The teaching content is mainly arranged around the theoretical knowledge such as the concept and basic principles of kindergarten curriculum. Although this content arrangement is beneficial for students to master systematic theoretical knowledge, for students, they only know the relevant theoretical knowledge in class, and do not know how to apply the theoretical knowledge to practice. Lead to the disconnection between the courses learned and practice. When students really enter kindergarten jobs, they have forgotten the relevant knowledge of the courses they have learned, and can only start new learning in practice.

\subsection{The Teaching Method Is Single, Mainly Traditional Teaching Method}

Facing the systematic declarative knowledge in teaching materials, teachers mainly adopt the traditional teaching method of teaching. For most teachers, they tend to sort out the knowledge in teaching materials and then pass on the knowledge to students by teaching. In the classroom, teachers are always in the state of outputting knowledge, while students are always in the state of inputting knowledge. At the beginning of the semester, students have initiative and enthusiasm in learning, and they can accept systematic theoretical knowledge taught by teachers. However, in the middle of the semester, students are in a state of exhaustion and are difficult to accept new knowledge. Traditional teaching method can no longer satisfy students' desire for knowledge, and they will find the course boring and difficult to understand. This teaching method affects students' learning effect. For most students, the knowledge in front of the textbook is mastered, while the knowledge behind of the textbook is in a blank state. Because teachers focus on explaining knowledge and neglect students' interest, students lose their enthusiasm and interest in learning courses.

\subsection{Teaching Evaluation Pays Attention to Scores and Focuses on Result Evaluation}

The main way to assess the "Introduction to kindergarten curriculum" is the final closed-book examination, and usually the result evaluation accounts for $60 \%$ of the total evaluation. Students utilizing just a few days to memorize relevant knowledge points, and finally how well they master the course depends mainly on the scores of the final papers. In the evaluation of students, the process evaluation only accounts for a part, and the proportion is small, and the result evaluation is still the main one. This causes students to have the idea that as long as they remember the relevant knowledge points carefully before the exam, their performance in class at ordinary times is not important for the understanding and application of knowledge. Over time, students pay attention to scores, ignore the feelings and performances in the process, and ignore whether they really master the relevant contents of the course. 


\section{The Reform and Innovation of "Introduction to Kindergarten Curriculum" in Application-Oriented Private Universities}

\subsection{Taking the Problem as the Main Line and Optimizing the Course Content}

"Problem-centered orientation" pays attention to the problems of individual and social production, starting from social problems and students' needs, interests and abilities (Wang \& Qin, 2019). The training goal of "Introduction to Kindergarten Curriculum" is to apply the theoretical knowledge related to the curriculum to practice. In teaching, teachers should focus on students' problem solving, systematic knowledge is a part, and more importantly, students' understanding of knowledge. Teachers should throw questions to students from time to time based on the knowledge related to the curriculum and combined with the actual teaching cases in kindergartens, so as to encourage students to think and solve problems. In the process of solving problems, students can have a deeper understanding of the relevant knowledge of the course and know how to deal with similar problems in practice.

\subsection{Taking Students as the Main Body and Changing Teaching Methods}

Traditional and single teaching methods cannot meet the needs of modern college students. Teachers need to change teaching methods in class to attract students' attention and interest, and realize students as the main body in class.

First, stimulate students' interest in learning through game teaching. With the reform and continuous progress of education in China, teachers' teaching behavior and teaching methods are also constantly updated. "Game teaching method" has been widely used in the educational activities of primary and secondary schools. Game teaching method belongs to an intuitive and new educational teaching method, which combines "game" with "teaching" closely and entertains, so as to create an efficient classroom (Zhang, 2021). Game teaching method is also applicable to universities. "Introduction to Kindergarten Curriculum" requires students not only to understand the basic knowledge of kindergarten curriculum, but also to remember important knowledge points. Classroom teaching can help students understand knowledge, and at the end of each chapter, they can help students remember important knowledge points by playing games. For example, students can be helped to remember through the game "pass the parcel". The teacher plays music and pauses randomly. When the music stops, which student stops the teaching aid in his hand and which student needs to answer the teacher's questions. Because the pause of music is random, all students need to understand and memorize relevant knowledge points so that they can answer teachers' questions in time. Another game is "You draw and I guess", in which the teacher randomly points three students to the front and shows them the hand cards prepared by the teacher in advance. Students describe the nouns ac- 
cording to the hand card, combine what the teacher said, and describe the nouns according to their own understanding. Other students say the corresponding nouns according to the description. These two games can be played at the end of each chapter of the course, which can deepen the understanding and memory of theoretical knowledge in interesting games.

Second, use modern teaching methods to combine rain classroom with curriculum. With the rapid development of the Internet, the modernization of education has become the focus of national attention. The combination of network and education has brought about great changes in the teaching environment, teaching resources, teaching tools, teaching methods and teacher-student interaction in traditional education (Liu, 2020). Through real-time information push and interaction, rain classroom not only narrows the distance between teachers and students and teaching content, but also can track, monitor and evaluate the whole teaching process in real time, which improves the flexibility of teaching (Liu \& Xia, 2020; Dong et al., 2021). In the teaching of "Introduction to Kindergarten Curriculum", teachers send PPT to the rain class before each class, which is convenient for students to know the relevant contents in advance, and promote all students to understand what the teacher said more clearly. After each class, the teacher can send relevant exercises in the rain class, and the system will automatically score the students after they finish. Through the analysis of rain class, teachers can understand the students' mastery of the content, and further explain the content with more questions. In addition, teachers can also upload excellent teaching cases and videos in the rain class. Everyone needs to watch the teaching video class together. When students want to watch it further after class, they can watch it repeatedly directly through the rain class. Rain classroom is a means in teaching. Using modern information technology, students can master the course content deeply and carefully, and help students better understand their mastery. It can not only promote teachers to master new information technology, enrich classroom content, but also help teachers better understand students.

Starting from stimulating students' interest and changing from "teaching before learning" to "learning before teaching", students' initiative and enthusiasm can be improved, and students can be the main body.

\subsection{Focusing on Process Evaluation, Enrich the Evaluation Methods}

Process assessment pays attention to students' usual performance, which can better enhance learners' professional quality. In the teaching of "Introduction to Kindergarten Curriculum", the classroom is handed over to students by using the teaching mode of flipping classroom. Flipping classroom can achieve student-centered learning goals, and has many advantages in improving teaching quality, such as realizing students' personalized learning, realizing effective interaction between teachers and students, and cultivating students' high-order thinking ability such as learning interest, cooperative inquiry and problem solving 
(Cai, 2019). In class, learners discuss together, design a complete kindergarten curriculum plan, implement the plan, and finally teachers and students evaluate it together. During the whole process from the design and implementation of kindergarten education activities by learners to the mutual evaluation between students, teachers observe and record learners' performance, evaluate learners' performance in a timely manner, and learners improve according to teachers' evaluation. Flipping classroom occupies most of the process evaluation. In addition, the process evaluation can also include learners' classroom performance, classroom discussion, after-class unit theme activity formulation, classroom report and other forms. Process evaluation accounts for $60 \%$, and result evaluation, that is, final test, accounts for $40 \%$. This evaluation method can stimulate learners' initiative and enthusiasm, and change learners' idea that they only pay attention to results and neglect processes. The evaluation method based on process evaluation is also more in line with the training objectives of application-oriented private universities.

To sum up, facing the challenges in the teaching of "Introduction to Kindergarten Curriculum", we should create problem situations, set up rich games, and make use of modern information technology (Rain class, Flip classroom) to be student-centered and focus on process evaluation. Only in this way can we realize the innovation of curriculum and the training goal of application-oriented private universities.

\section{Conflicts of Interest}

The author declares no conflicts of interest regarding the publication of this paper.

\section{References}

Cai, J. (2019). Understanding the Adoption and Continuous Use of Flipped Classroom by Instructors and Students from the Perspective of Teaching System. Central China Normal University.

Dong, G. W., Zhao, G. Q., Zheng, C., Song, L. B., \& Wang, X. H. (2021). Design and Practice of Virtual Simulation Experiment Teaching Mode Based on Rain Class. Research and Exploration in Laboratory, 10, 215-218.

Lei, H. F., Kong, J. H., Bai, L., \& Sun, L. (2020). Construction of Teacher Training Management Mode in Private Application-Oriented Undergraduate Universities-Taking the Reform Ideas of Shandong Huayu Institute of Technology as an Example. Chinese University Science \& Technology, 7, 81-84.

Li, M. L. (2020). Researches on the Teachers' Performance Management in Guangdong's Application-Oriented Private College A. Guangdong University of Technology.

Liu, J. C., \& Li, X. Q. (2021). The Practical Character of the Teaching of Kindergarten Curriculum Theory. Journal of Educational Development, 6, 55-61.

Liu, T. (2020). Design and Practice Research of Interactive Teaching Strategy Based on Rain Classroom. Guangxi Normal University.

Liu, X. F., \& Pei, X. F. (2019). A Probe into the Curriculum Reform of Preschool Education Based on the Training of Applied Professionals. Theory and Practice of Education, 
$33,49-51$.

Liu, Y., \& Xia, X. Q. (2020). Motivation, Problems and Countermeasures of Rain Classroom Helping to Create "Golden Course" of Ideological and Political Education in Colleges and Universities. Social Sciences in Guangxi, 8, 177-182.

Wang, C. Y., \& Qin, Y. D. (2019). You'eryuan Kecheng Gailun (3rd ed.). Higher Education Press.

Xu, X. L. (2019). Thoughts on the Talents Training Mode of Preschool Education in Applied Universities. Education and Vocation, 6, 41-44.

Zhang, L. Y. (2021). Research on the Application of Game Teaching in Music Class of Junior Middle School. Henan University of Science and Technology. 